\title{
Peranan Sistem Informasi Manajemen Dalam Meningkatkan Kinerja Karyawan Pada Tirta Bina Labuhanbatu
}

\author{
Elvitrianim Purba \\ Prodi Manajemen Informatika, AMIK Stiekom Sumatera Utara, Rantauprapat, Indonesia \\ Email: elvitrianim40@gmail.com
}

\begin{abstract}
Abstrak-Sistem Informasi Manajemen (SIM) merupakan sistem yang mengolah serta mengorganisasikan data dan informasi yang berguna untuk mendukung pelaksanaan tugas dalam suatu organisasi / Pereusahaan. Suatu perusahaan akan menggunakan sistem informasi untuk meningkatkan / membantu para karyawan agar dapat menunjang kinerja mereka. SIM sangat pengaruh penting bagi perusahaan karena peranya sangat vital atau sangat berdampak untuk perusahaan itu sendiri. Dengan penggunaan SIM perusahaan dapat memiliki keuntungan dalam proses bisnis didalam perusahaan. Proses-proses dalam bisnis yang sebelumnya tidak menggunakan SIM akan memakan waktu yang cukup lama. Dengan menggunakan SIM akan memiliki keuntungan bagi perusahaan karena proses-proses bisnis dapat dipersingkat atau di permudah. Dalam penggunaannya SIM memiliki sistem yang dapat membantu kinerja karyawan dalam perusahaan. Sehingga perusahaan tidak perlu memakan waktu yang cukup lama dalam beberapa proses bisnisnya
\end{abstract}

Kata Kunci: System Informasi Manajemen (SIM); Kinerja Pegawai

Abstract-Management Information System (MIS) is a system that processes and organizes useful data and information to support the implementation of tasks in an organization/company. A company will use information systems to improve / assist employees to support their performance. SIM is very important for the company because its role is very vital or very impactful for the company itself. With the use of SIM companies can have advantages in business processes within the company. Processes in a business that previously did not use a SIM will take a long time. Using SIM will have advantages for the company because business processes can be shortened or simplified. In its use, SIM has a system that can help the performance of employees in the company. So the company does not need to take a long time in some of its business processes.

Keywords: Management Information System (MIS); Employee Performance

\section{PENDAHULUAN}

Seiring perkembangan zaman, teknologi dan sistem informasi ikut berkembang menjadi lebih canggih dan berdampak positif bagi masyarakat luas termasuk instansi pemerintah negeri maupun swasta. Organisasasi menyadari bahwa informasi merupakan kebutuhan mendasar dan telah menjadi sumber daya penting yang harus dikelola dengan baik. Dengan demikian, adanya teknologi dan sistem informasi akan memudahkan untuk memperoleh informasi dengan melakukan pengolahan data-data dengan lebih cepat, akurat, efektif, dan efisien. Tegasnya, informasi digunakan untuk mendukung proses pengambilan keputusan yang dapat memberikan keunggulan kompetitif.

Sistem Informasi Manajemen memiliki peran dan manfaat yang signifikan antara fasilitas pengolah data dengan pegawai sebagai user, dimana keterkaitan antara satu unit dengan unit lainnya akan saling terintegrasi dalam proses pengumpulan data, pemrosesan data, penyimpanan data, umpan balik data, serta pendistribusian data terhadap internal dan eksternal organisasi.

Proses peningkatan kinerja pegawai dalam satu organisasi dapat dilihat dari fasilitas yang mendukung para pegawai dalam mengolah data-data yang berupa informasi demi tercapainya tujuan organisasi. Dimana sistem informasi akan sangat dibutuhkan sebagai sarana organisasi dalam menyampaikan keputusan yang telah diambil dari data-data yang diproses

Selain pegawai, organisasi juga harus menyadari bahwa informasi adalah kebutuhan mendasar dan merupakan sumber daya penting yang harus dikelola dengan baik. Dengan demikian, dengan adanya teknologi dan sistem informasi akan memudahkan dalam memperoleh informasi serta memepercepat organisasi dalam menyebarkan informasi agar terhindar dari kesalahan-kesalahan yang tak terduga akibat keterlambatan informasi

\section{KERANGKA TEORI}

\subsection{Sistem Informasi Manajemen}

Sistem Informasi Manajemen adalah serangkaian sub-sistem informasi yang menyeluruh dan terkoordinasi dan secara rasional terpadu yang mampu mentransformasi data sehingga menjadi informasi lewat serangkaian cara guna meningkatkan produktivitas yang sesuai dengan gaya dan sifat manajer atas dasar kriteria mutu yang telah ditetapkan. Scott (dalam Nashir, 2002:100) menyimpulkan beberapa ciri-ciri dari SIM jika ditinjau dari pengertian diatas yaitu sebagai berikut:

1. Sistem Informasi Manajemen (SIM) adalah menyeluruh

2. Sistem Informasi Manajemen (SIM) adalah terkoordinasi

3. Sistem Informasi Manajemen (SIM) memiliki sub-sistem informasi

4. Sistem Informasi Manajemen (SIM) terintegrasi secara rasional

5. Sistem Informasi Manajemen (SIM) mentransformasikan data ke dalam informasi dengan berbagai cara 
6. Sistem Informasi Manajemen (SIM) meningkatkan produktivitas

7. Sistem Informasi Manajemen (SIM) sesuai dengan sifat dan gaya manajer

8. Sistem Informasi Manajemen (SIM) menggunakan kriteria mutu yang telah ditetapkan. Syarat-syarat sistem informasi manajemen yang baik menurut Kumorotomo (1998:111) yaitu sebagai berikut :

1. Ketersediaan Syarat yang mendasar bagi suatu informasi adalah tersedianya informasi itu sendiri. Informasi harus dapat diperoleh bagi ornag yang hendak memanfaatkannya.

2. Mudah dipahami Informasi harus mudah dipahami dan tidak berbelit-belit yang hanya akan mempelambat proses manajemen.

3. Sesuai Informasi harus benar-benar sesuai dengan tujuan dan permasalahan di dalam organisasi.

4. Bermanfaat Informasi harus tersaji ke dalam bentuk-bentuk yang bersangkutan.

5. Ketepatan waktu Informasi yang tersedia harus tepat waktu terutama pada saat organisasi membutuhkan informasi ketika manajer hendak membuat keputusan.

6. Kehandalan Informasi harus diperoleh dari sumber-sumber yang dapat diandalkan kebenarannya. Pengolah data atau pemberi informasi harus dapat menjamin tingkat kepercayaan yang tinggi atas informasi yang disajikan.

Sistem informasi manajemen memberikan dukungan dalam pengumpulan informasi atau perancangan rangkaian alternatif tindakan, memutuskan untuk memilih tindakan dari alternatif yang tersedia dan melaksanakan pilihan dan mengawasi hasil kegiatan. Sistem informasi dapat digunakan secara efektif untuk mendukung setiap tindakan pada proses pengambilan keputusan dan dapat digunakan juga untuk memperoleh dan menyimpan informasi yang berkaitan dengan masalah, standard dan situasi sekarang. Sistem informasi manajemen juga sangat membantu dalam merealisasikan keputusan dalam tindakan dan mengawasi tindakan serta memberikan umpan balik yang berkaitan dengan hasilnya. Dengan demikian sistem informasi manajemen akan mendukung setiap langkah pengambilan keputusan dari langkah identifikasi masalah sampai menetapkan pemilihan solusinya. (Kristanto, 2003:27)

\subsection{Pengolahan Data}

Pengolahan data menurut Kristanto (2006:8) adalah waktu yang digunakan untuk menggambarkan perubahan bentuk data menjadi informasi yang memiliki kegunaan. Adapun Sutabri (2012:109) mengungkapkan bahwa pengolahan data adalah suatu proses menerima data sebagai masukan (input), memproses (processing) menggunakan program tertentu, dan mengeluarkan hasil proses data tersebut dalam bentuk informasi (output). Oleh karena itu, pengolahan data terdiri dari 3 (tiga) langkah yaitu input, processing, dan output. Siklus pengolahan data yang dikemukan oleh Kristanto (2003:9) adalah sebagai berikut :

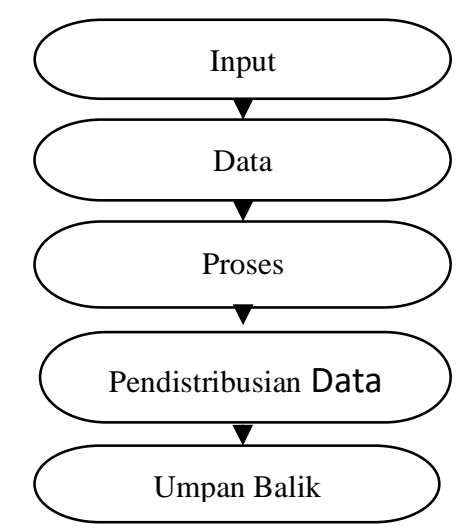

Gambar 1. Siklus pengolahan data

Gambar 1 dapat dijelaskan bahwa data yang merupakan suatu kejadian yang menggambarkan kenyataan yang terjadi dimasukkan melalui elemen iput Input Proses Data Pendistribusian data Umpan balik kemudian data tersebut akan diolah dan diproses menjadi suatu output dan output tersebut adalah informasi yang dibutuhkan. Informasi tersebut kemudian akan diterima oleh pemakai atau penerima, kemudian penerima akan memberikan umpan balik yang berupa evaluasi terhadap informasi dan umpan balik tersebut akan menjadi data yang akan dimasukkan menjadi input kembali untuk kepentingan selanjutnya dan begitu juga seterusnya secara berkesinambungan.

\subsection{Sistem Informasi Manajemen Berbasis Komputer}

Sistem informasi manajemen (Sutabri, 2012:99) terdiri dari manusia, perangkat keras, perangkat lunak, data, dan prosedur-prosedur organisasi yang saling berinteraksi untuk menyediakan data dan informasi yang tepat kepada pihakpihak baik di dalam maupun di luar organisasi yang berkompeten. Semakin banyak data yang akan diolah oleh organisasi baik organisasi besar maupun organisasi kecil akan sangat membutuhkan metode yang tepat akan data lebih akurat. Maka metode pengolahannya data dilakukan dengan menggunakan komputer. Dengan menggunakan komputer, semua permasalahan dapat diselesaikan secara cepat baik itu permasalahan secara sistematis ataupun fungsifungsi lainnya. Selain itu, dengan menggunakan komputer dapat meminimalisir kesalahan saat mengelola data. 
Secara teknis pelaksanaan sistem informasi manajemen berbasis komputer meliputi 4 tahapan yaitu:

1. Input. Perkakas input berfungsi menyediakan data mentah ke komputer system

2. Pengolahan. Data yang telah diinput kemudian diolah atau diproses oleh CPU sesuai dengan instruksi-instruksi yang diberikan oleh perangkat lunaknya.

3. Penyimpanan. Pada saat komputer menjalankan fungsinya, maka komputer akan mengalirkan dan menyimpan data dalam ruang elekronik yang disebut memori.

4. Output. Setelah informasi diperoleh, informasi tersebut diberikan kepada perangkat output.

Sistem informasi manajemen berbasis komputer dalam Sutabri (2012:99) dikatakan bahwa sistem informasi manajemen menempatkan perkakas pengolah data komputer dalam kedudukan yang penting. Alasannya yaitu berkenaan dengan kemampuan komputer mengolah data yang mampu menyerap dan mencatatp data lebih unggul dibandingkan dengan daya ingat manusia sekalipun pengambilan keputusan dilakukan oleh manusia. Alasan berikutnya yaitu tentang pentingnya pemakaian komputer dalam sistem informasi manajemen adalah bahwa teknologi yang otomatis melalui komputerisasi yang sudah berkembang pesat dimana-mana.

\subsection{Kinerja Pegawai}

Kinerja berasal dari kata job performance dan disebut juga actual performance atau prestasi kerja atau prestasi sesungguhnya yang telah dicapai oleh seseorang pegawai (Moeheriono, 2010:61). Sedangkan Kusriyanto (dalam Anwar, 2009:9) berpendapat bahwa kinerja adalah perbandingan hasil yang dicapai dengan peran serta tenaga kerja persatuan waktu.

Oleh karena itu, seorang pegawai harus mampu meningkatkan kemampuan dan keterampilannya dan juga motivasi kerja tidak dapat diabaikan. Walaupun kemampuan pegawai dikategorikan baik namun apabila motivasi kerjanya sangat rendah, tentu kinerjanya juga akan rendah. Kriteria keberhasilan itu berupa tujuan atau target yang telah dicapai. Tanpa target dan tujuan, maka kinerja seorang pegawai tidak mungkin diketahui karena tidak ada tolak ukurnya. Berdasarkan uraian di atas disimpulkan bahwa kinerja merupakan hasil kerja atau outcome yang dihasilkan oleh pegawai dalam satuan waktu dimana hasil kerja pegawai dibandingkan dengan waktu yang digunakan untuk mencapai hasil sehingga dapat dilakukan penilaian terhadap hasil kerjanya. Hasil kerja tersebut merupakan hasil yang dikerjakan oleh pegawai itu sendiri dari kewajiban yang menjadi bagiannya sebagai pegawai sesuai tugas pokok dan fungsi pada jabatan yang dimiliki.

Menurut Sutrisno (2009:176) terdapat faktor-faktor yang mempengaruhi kinerja pegawai yaitu sebagai berikut:

1. Efektivitas dan Efisiensi Baik buruknya kinerja organisasi diukur dari efektivitas dan efisiensi kerja. Misalnya, organisasi dikatakan efektif bila mampu mencapai tujuan dan dikatakan efisien bila hal itu memuaskan sebagai pendorong mencapai tujuan. Artinya bila tujuan organisasi dapat dicapai sesuai dengan kebutuhan yang direncanakan. Sedangkan efisien berkaitan dengan jumlah pengorbanan yang dikeluarkan dalam upaya mencapai tujuan organisasi.

2. Otoritas dan Tanggung Jawab Wewenang dan tanggung jawab dalam organisasi telah didelegasikan dengan baik tanpa adanya tumpang tindih tugas. Masing-masing pegawai yang ada dalam organisasi mengetahui apa yang menjadi hak dan tanggung jawabnya dalam rangka mencapai tujuan organisasi. Kejelasan wewenang dan tanggung jawab setiap pegawai dalam suatu organisasi akan mendukung kinerja pegawai tersebut. Kinerja pegawai dapat terwujud bila mempunyai komitmen dengan organisasinya dan ditunjang dengan disiplin kerja yang tinggi.

3. Disiplin Secara umum, disiplin menunjukkan suatu kondisi atau sikap hormat yang ada pada diri pegawai terhadap peraturan dan ketepatan organisasi. Disiplin meliputi ketaatan dan hormat terhadap perjanjian yang dibuat antar organisasi dengan pegawai. Dengan demikian, bila peraturan atau ketetapan yang ada pada organisasi itu diabaikan dan sering dilanggar, maka pegawai mempunyai disiplin yang buruk. Sebaliknya, bila pegawai tunduk pada ketetapan organisasi, hal itu menggambarkan adanya disiplin yang baik.

4. Inisiatif Inisiatif seseorang berkaitan dengan daya piker, kreativitas dalam bentuk ide untuk merencanakan sesuatu yang berkaitan dengan tujuan organisasi. Setiap inisiatif sebaiknya mendapat perhatian dan tanggapan positif atasan.

Sistem penilaian kinerja memiliki manfaat yang baik untuk berbagai kepentingan organisasi antara lain:

1. Mendorong peningkatan kinerja yaitu dengan mengetahui hasil prestasi kerja, pihak yang terlibat dapat megambil berbagai langkah yang diperlukan agar kinerja para pegawai lebih meningkat lagi di masa mendatang.

2. Sebagai bahan pengambilan keputusan dalam pemberian imbalan, keputusan tentang siapa yang berhak menerima imbalan berdasarkan penilaian atas kinerja pegawai.

3. Untuk kepentingan mutasi yaitu kinerja seseorang dimasa lalu merupakan dasar bagi pengambilan keputusan mutasi baginya dimasa yang akan datang ataupun bentuk mutasi seperti promosi, alih tugas, atau alih wilayah kerja.

4. Guna menyusun program pendidikan dan pelatihan, hal ini dimaksudkan untuk mengatasi berbagai kekurangan dan kelemahan maupun untuk mengembangkan potensi pegawai yang ternyata sepenuhnya digali dan terungkap melalui penilaian kinerja pegawai.

Penilaian kinerja bertujuan untuk memperbaiki atau meningkatkan kinerja organisasi melalui peningkatan kinerja dari sumber daya manusia (SDM) dalam organisasi. Sunyoto (dalam Mangkunegara, 2006:240) mengemukakan beberapa tujuan dari evaluasi kinerja yaitu sebagai berikut:

1. Meningkatkan saling pengertian antar pegawai tentang persyaratan kinerja. Penilaian atas kinerja para pegawai harus terdapat interaksi yang positif yang positif dan berkesinambungan antara pemimpin dan pegawai. Penilaian 
yang dilakukan berkaitan langsung dengan tugas seorang pegawai serta kriteria yang ditetapkan dan yang diterapkan secara objektif sehingga pada gilirannya memuaskan bagi pegawai karena memperoleh perlakuan yang adil.

2. Mencatat dan mengakui hasil kerja seorang pegawai. Hal ini dilakukan agar pegawai termotivasi untuk berbuat yang lebih baik atau sekurang-kurangnya berprestasi sehingga dapat dijadikan sebagai ukuran sejauh mana pegawai ini dapat menyelesaikan pekerjaannya.

3. Memberikan peluang kepada pegawai untuk mendiskusikan keinginan dan aspirasinya dan meningkatkan kepedulian terhadap karier atau pekerjaan yang diembannya. Dengan adanya penilaian kinerja maka akan membantu organisasi dalam memberikan kesempatan bagi setiap pegawai dalam memaksimalkan potensinya.

4. Mendefenisikan dan merumuskan kembali sasaran masa depan sehingga pegawai termotivasi untuk berprestasi sesuai dengan potensinya.

Mengupayakan agar pegawai tidak cepat puas dengan apa yang telah mereka capai, artinya meskipun kinerjanya dimasa lalu dianggap sedah cukup memuaskan, tetapi tetap perlu ditanamkan kesadaran bahwa kinerja yang memuaskan masih harus ditingkatkan. Apabila kinerja telah memuaskan maka pegawai akan termotivasi untuk berprestasi kedepannya Memeriksa rencana pelaksanaan dan pengembangan sesuai kebuthan pelatihan dan kemudian menyetujui rencana jika ada hal yang perlu diubah. Analisa kerja yang telah diperoleh akan membantu evaluasi kebutuhan pelatihan diri bagi para pegawai melalui berbagai audir keterampilan dan pengetahuan sehingga dapat mengembangkan kemampuan dirinya pada akhirnya dapat menghasilkan potensi pegawai mana yang berhak memperoleh promosi atau hal lainnya

\subsection{Kerangka Konseptual}

Berikut kerangka konseptual dalam penelitian yang dilakukan.

Sistem Informasi Manajemen (SIM) (X) $\longrightarrow$ Kinerja Pegawai (Y)

Gambar 2. Kerangka konseptual

\section{METODOLOGI PENELITIAN}

\subsection{Teknik Analisis Data}

Data penelitian yang terkumpul akan dianalisis melalui pendekatan kuantitatif dengan menggunakan teknik sebagai berikut:

\subsubsection{Uji Instrumen}

\section{a. Uji Validitas}

Menurut Arikunto (2010:211) validitas adalah suatu ukuran yang menunjukkan tingkat kevalidan atau kesahihan suatu instrument. Suatu instrument yang valid mempunyai validitas tinggi, sebaliknya instrumen yang kurang valid berarti memiliki kualitas yang rendah. Uji validitas digunakan untuk mengukur sah atau valid tidaknya suatu kuisioner. Kuisioner dikatakan valid jika pertanyaan pada kuisioner mampu untuk mengungkapkan sesuatu yang akan diukur olehkuisioner tersebut. Adapun rumus untuk menguji validitas yaitu:

$$
x_{r y}=\frac{N \sum x y-\left(\sum x\right)\left(\sum y\right)}{\sqrt{\left(N \sum x^{2}-\left(\sum x\right)^{2}\left(N \sum y^{2}-\left(\sum y\right)^{2}\right.\right.}}
$$

Keterangan :

$x_{r y}=$ koefisien korelasi antara variabel $\mathrm{X}$ dan variabel $\mathrm{Y}$

$\sum \mathrm{xy}=$ jumlah perkalian antara variabel $\mathrm{X}$ dan $\mathrm{Y}$

$\sum x^{2}=$ jumlah dari kuadrat nilai $X$

$\sum y^{2}=$ jumlah dari kuadrat nilai $\mathrm{Y}$

$\left(\sum y\right)^{2}=$ jumlah nilai $\mathrm{X}$ kemudian dikuadratkan

$\left(\sum y\right)^{2}=$ jumlah nilai $\mathrm{Y}$ kemudian dikuadratkan

Suatu data dikatakan valid apabila $x_{r y} \geq 0,3$

\section{b. Uji Reliabilitas}

Arikunto (2010:213) berpendapat bahwa reliabilitas merupakan instrumen yang cukup dapat dipercaya untuk dapat digunakan sebagai alat pengumpul data karena intrumen tersebut sudah baik. Adapun rumus yang digunakan adalah:

$$
r_{11}=\left(\frac{n}{n-1}\right)\left(1-\frac{\sum \sigma_{t}^{2}}{\sigma_{t}^{2}}\right)
$$

Keterangan :

$r_{11}=$ reliabilitas yang dicari

$\mathrm{n}=$ jumlah item pertanyaan yang di uji 
$\sum \mathrm{b} \sigma^{2} b=$ jumlah varian butir

$\sigma^{2} t=$ varians total

\subsubsection{Metode Analisis Data}

\section{a. Metode Analisis Deskriptif}

Metode analisis deskriptif yaitu suatu metode analisis dimana data yang dikumpulkan mula-mula disusun dan diklarifikasikan sehingga akan memberikan gambaran mengenai suatu keadaan.

\section{b. Metode Analisis Regresi Sederhana}

Metode regresi sederhana adalah metode statistik yang berfungsi untuk menguji sejauh mana hubungan sebab akibat antara variabel sistem informasi manajemen $(\mathrm{X})$ terhadap kinerja pegawai $(\mathrm{Y})$. Model persamaan regresi linier sederhana adalah sebagai berikut: $\quad \mathrm{Y}=\mathrm{a}+\mathrm{bX}+\mathrm{e}$

\subsubsection{Uji Asumsi Klasik}

\section{a. Uji Normalitas}

Uji normalitas adalah untuk melihat apakah residual terdistribusi normal atau tidak. Model regresi yang baik adalah memiliki residual yang terdistribusi normal. Jadi uji normalitas bukan dilakukan pada masing-masing variabel tetapi pada nilai residualnya. Sering terjadi kesalahan jamak yaitu bahwa uji normalitas dilakukan pada masing-masing variabel, hal ini tidak dilarang tetapi model regresimemerlukan normalitas pada nilai residualnnya bukan pada masingmasing variabel penelitian.

\section{b. Uji Hipotesis}

\section{Uji t}

Untuk membuktikan apakah setiap variabel bebas (X) mempunyaipengaruh yang signifikan terhadap variabel terikat (Y) secara parsial.

Kriteria pengujian adalah sebagai berikut:

Ho: ${ }_{1}=0$, artinya tidak terdapat pengaruh sistem informasi manajemen terhadapkinerja pegawai.

Ho: $1 \neq 0$, artinya terdapat pengaruh sistem informasi manajemen terhadap kinerjapegawai.

Dengan kaidah pengambilan keputusan yaitu:

Ho ditolak jika $t_{\text {hitung }}<t_{\text {tabel }}$ pada tabel $\alpha=5 \%$ Ha diterima

jika $t_{\text {hitung }}>t_{\text {tabel }}$ pada tabel $\alpha=5 \%$

Penelitian ini memerlukan bantuan software statistik SPSS (statisticproduct and service solutions) dalam menganalisis data.

Ho: $1=0$, artinya tidak terdapat pengaruh sistem informasi manajemen terhadap kinerja pegawai.

Ho: $\neq \neq 0$, artinya terdapat pengaruh sistem informasi manajemen terhadap kinerjapegawai.

Dengan kaidah pengambilan keputusan yaitu:

Ho ditolak jika $t_{\text {hitung }}<t_{\text {tabel }}$ pada tabel $\alpha=5 \%$ Ha diterima

jika $t_{\text {hitung }}>t_{\text {tabel }}$ pada tabel $\alpha=5 \%$

Penelitian ini memerlukan bantuan software statistik SPSS (statisticproduct and service solutions) dalam menganalisis data.

\section{Koefisien Determinasi}

Analisis koefisien determinasi dilakukan untuk mengetahui seberapa besar pengaruh variabel independen $(X)$ terhadap variabel dependen (Y). Semakin besar nilai determinasi semakin besar kemampuan variabel independen menerangkan variabel dependen. Hal ini berarti model yang digunakan semakin kuat untuk menerangkan pengaruh variabel bebas yang diteliti terhadap variabel terikat. Sebaliknya jika determinasi R2 semakin kecil (semakin mendekat) maka dapat dikatakan bahwa pengaruh variabel independen terhadap variabel dependen semakin kecil.

Rumus untuk koefisien determinasi $\left(r^{2}\right)$ :

$\mathrm{KD}=r^{2} \times 100 \%$

Keterangan :

$$
\begin{aligned}
\mathrm{KD} & =\text { Koefisien determinasi } \\
r^{2} & =\text { Koefisien korelasi }
\end{aligned}
$$

\section{HASIL DAN PEMBAHASAN}

Penelitian ini menggunakan dua variabel yaitu variabel sistem informasi manajemen (X) dan variabel kinerja (Y). Penelitian pada variabel sistem informasi manajemen ini menunjukkan hasil yang cukup baik. Hal ini dapat dilihat dari jawaban positif responden yang dibagi menjadi 4 indikator yaitu SIM membantu dalam pengambilan keputusan, SIM sebagai pendukung fungsi perencanaan, SIM memberi informasi yang lengkap dan tepat, dan SIM sebagai penentuan penentuan program kerja. Berdasarkan ke-4 indikator tersebut kemudian dikembangkan menjadi 15 pernyataan mengenai sistem informasi manajemen yang dapat mengukur baik atau tidaknya sebuah sistem informasi manajemen yang diterapkan dalam perusahaan. 
Berdasarkan hasil pengolahan data kuisioner, maka dapat diperoleh identitas responden didominasi oleh responden yang berjenis kelamin laki-laki. Usia responden terbanyak yaitu antara 40-49 tahun. Pada karakteristik responden dengan lama bekerja secara keseluruhan responden telah bekerja di atas 3 tahun.

Selanjutnya pada variabel kinerja perhitungan yang dilakukan dari hasil jawaban responden melalui kuisioner yang disebar kepada 45 responden, respon positif tertinggi dengan kategori setuju (sangat setuju dan setuju) terdapat pada indikator 3 dengan butir pernyataan bahwa dengan diterapkannya SIM pengelolaan data lebih cepat dibandingkan dengan cara manual/biasa dengan jumlah sebesar 198 dimana terdapat 18 responden yang menjawab sangat setuju, 27 responden menjawab setuju. Oleh karena itu, pada butir pernyataan ini memperoleh persentase tertinggi dari jawaban responden yang menyatakan setuju dibandingkan dengan pernyataan lainnya yaitu sebesar 100\%. Berdasarkan persentase tersebut dapat kita lihat bahwa dengan diterapkannya SIM pengelolaan data dilakukan lebih cepat dibandingkan cara manual/biasa dinyatakan sangat baik. Sebaliknya, jumlah jawaban resonden terendah dengan persentase sebesar $57,8 \%$ terdapat pada indikator kedua dengan butir pernyataan bahwa penundaan penyelesaian pekerjaan sering terjadi akibat jumlah beban kerja dan waktu tidak sesuai dengan jumlah 168. Oleh karena itu, dapat dilihat bahwa apabila beban dan waktu tidak sesuai bukan berarti alasan untuk menunda pekerjaan dan hal ini dapat dikategorikanbaik untuk variabel kinerja.

Hasil uji validitas pada variabel sistem informasi manajemen, seluruh butir penyataan dinyatakan valid. Hal ini dapat dilihat dari tabel validitas dengan nilai > dimana nilai $r$ tabel sebesar 0,29396. Begitu juga pada variabel kinerja, seluruh butir pernyataan dinyatakan valid dengan nilai sebesar 0,29396. Hasil uji reliabilitas untuk variabel sistem informasi manajemen dengan nilai cronbach's alpha sebesar 0,861, sehingga dapat disimpulkan bahwa nilai $\mathrm{r}$ alpha positif dan lebih besar $\mathrm{r}$ tabel $(0,861>0,6)$ terdapat pada tabel 4.46 , maka instrumen yang digunakan dalam penelitian ini merupakan instrument yang reliabel. Pada variabel kinerja dengan nilai cronbach's alpha sebesar 0,829, sehingga dapat disimpulkan bahwa nilai $r$ alpha positif lebih atau lebih besar dari $r$ tabel $(0,829>0,6)$ terdapat pada tabel 4.47 , maka instrument yang digunakan dalam penelitian yang reliabel.

Hipotesis diterima apabila nilai $t_{h i t u n g}>t_{\text {tabel }}$. Nilai $t_{h i t u n g}$ dapat di lihat pada tabel yaitu sebesar 11,252 sedangkan untuk nilai $t_{\text {tabel }}$ dapat dilihat pada tabel statistik pada signifikansi 0,05 yaitu sebesar 2,017. Maka dapat disimpulkan nilai $t_{\text {hitung }}>t_{\text {tabel }}(11,252>2,017)$ maka hipotesis diterima. Jadi dapat disimpulkan bahwa sistem informasi manajemen berpengaruh signifikan terhadap kinerja. Nilai thitung positif berarti pengaruhnya positif, yaitu jika sistem informasi manajemen baik maka tingkat kinerja juga akan baik. Berdasarkan signifikansi $0,000<0,05$ dinyatakan hipotesis nol (Ho) ditolak dan hipotesis kerja (H1) diterima.

Berdasarkan hasil perhitungan koefisien determinasi $\left(\mathrm{R}^{2}\right)$ menunjukkan bahwa hubungan antara sistem informasi manajemen dan kinerja adalah erat yang dapat dilihat pada tabel 4.51 dengan nilai $\mathrm{R}$ yaitu sebesar 0,864 atau sebesar $86,4 \%$. Kemudian pada nilai $R$ Square (koefisien determinasi) sebesar 0,746 atau sebesar 74,6\% menunjukkan bahwa variabel kinerja (Y) dapat dijelaskan oleh variabel sistem informasi manajemen (X), sedangkan sisanya sebesar $25,4 \%$ dipengaruhi oleh variabel lain yang tidak terdapat dijelaskan dalam penelitian ini.

\section{KESIMPULAN}

Dari hasil penelitian dapat disimpulan hasil dari uji t pada penelitian ini menunjukkan nilai thitung $>$ ttabel $(11,252>$ $2,017)$ yang berarti bahwa hipotesis diterima. Jadi dapat disimpulkan bahwa sistem informasi manajemen berpengaruh signifikan terhadap kinerja. Nilai thitung positif berarti pengaruhnya positif, yaitu jika sistem informasi manajemen baik maka tingkat kinerja juga akan baik. Hasil uji koefisien determinasi (R2) menunjukkan nilai R Square sebesar 0,746 atau sebesar 74,6\% menunjukkan bahwa variabel kinerja (Y) dapat dijelaskan oleh variabel sistem informasi manajemen (X). Selanjutnya pada hasil uji koefisein determinasi terdapat nilai R yaitu sebesar 0,864 atau sebesar $86,4 \%$ dimana nilai koefisien korelasi ini menunjukkan bahwa hubungan antara sistem informasi manajemen dan kinerja adalah erat.

\section{DAFTAR PUSTAKA}

Teguh, Hendra. Sistem Informasi Manajemen. Edisi Indonesia: PT Bhuana IlmuPopuler, 1995

Nashir, A.Budiman. Prinsip-Prinsip Sistem Informasi Bisnis. Jakarta: PTRajaGrafindo Persada, 2002

Kumorotomo, Wahyudi. Sistem Informasi Manajemen Dalam Organisasi-Organisasasi Publik. Yogyakarta: Gadjah Mada University Press, 1990

Kristanto, Andri. Perancangan Sistem Informasi dan Aplikasinya.Yogyakarta:Gava Media, 2006

Sutabri, Tata. Analisis Sistem Informasi. Yogyakarta:Andi, 2012

Moeheriono. Pengukuran kinerja berbasis kompetensi- competency based human resources management. Jakarta: Penerbit Ghalia Indonesia, 2010.

Siagian, Sondang P. Manajemen Sumber Daya Manusia. Jakarta: Bumi Aksara,2004

Mangkunegara, P. Anwar. Evaluasi Kinerja SUmber Daya Manusia. Bandung:PT. Refika Aditam, 2009 